Article

\title{
Law's Autonomy and Moral Reason
}

\author{
Jack Clayton Thompson $\mathbb{D}$
}

Brighton Business School, University of Brighton, Mithras House, Lewes Road, Brighton BN2 4AT, UK; j.c.thompson@brighton.ac.uk

Received: 10 October 2018; Accepted: 4 February 2019; Published: 15 February 2019

\begin{abstract}
This paper intends to set out an argument to Legal Idealism and a thesis that holds law and morality as necessarily connected. My focus is on deconstructing the Positivist argument to the Autonomy Thesis and beginning to reconstruct it through the application of morality to law's autonomous authority. My aim, ultimately, is to demonstrate how, through the concept of law, practical reason might explain the related (and overlapping) notions of legitimacy, authority, and the obligation to obey through the necessary connection of law and morality. That is, I intend to demonstrate that morality both survives and remains identifiable (transparently) following the process of metamorphosis into institutionalised practical reasoning. If this is so, the authority of and obligation to law is simultaneously a form of morally rational obligation. In the response to the Positivist argument that moral values are incommensurate, I will show that this commensurability can be determined 'artificially' by a system of institutionalised reasoning (i.e., the law); this is to say, if I can show that the Legal Positivist argument is left incomplete without some explanation of moral values underpinning it, I need not to show that a specific, defensible moral truth or principle is required, but that an artificial weighting of abstract moral principles is sufficient
\end{abstract}

Keywords: Positivism; Natural Law; Legal Theory; Legal Idealism; Gewirth; Morality; Authority of Law

\section{Introduction}

This paper holds that law and morality are necessarily connected. Its argument is located within what is generally referred to as Legal Idealism. This approach asserts that the basis on which there is a necessary connection between law and morality is that certain objectively between 'goods' or 'needs' for all agents exists (Beyleveld and Brownsword 1994, pp. 8-10). This posits Legal Idealism in the interstice between Natural Law Theory and Legal Positivism. The main argument of this paper is that it is possible to resolve the perennial debate between Natural Law Theory and Legal Positivism by adopting a position that argues for the grounding of legal enterprise on public morality. This will be done by focusing on the Legal Positivist argument to the Autonomy Thesis- the theory that law ought to be autonomous of moral reasoning-and by reconstructing it as an institutionalised theory of law and adjudication.

Legal Idealism rests on the meta-ethical view that certain moral truths or principles are knowable by reason alone. This is known as Moral Rationalism. Such a system of moral reasoning is premised on considering practical reasoning; the reasons for choosing to act in a certain way in a given situation, as well as, more broadly, the pursuit and selection of one's goals. For the Legal Idealist, the law can be understood as an attempt to regulate practical reason. As Palmer Olsen and Toddington (1999a, p. 3) note,

... law can be seen as the practically reasonable attempt to institutionalise and uphold in a society certain practical norms, which, because of the special authority which has arisen in the institutions and offices responsible for the positing, application and enforcement of these 
norms, are seen to possess a legitimate priority—an exclusionary validity —as against other norms in that society ...

It is this relation to practical reason that defines the ambit of this paper, and indeed may be used to explain the related (and overlapping) notions of legitimacy, authority, and the obligation to obey through the necessary connection of law and morality (Beyleveld and Brownsword 1994, p. 9). If this connection is said to exist, it must be shown that morality both survives and remains identifiable (transparently) following the process of metamorphosis into institutionalised practical reasoning (Palmer Olsen and Toddington 1999a, p. 26). If this is so, the authority of and obligation to law is simultaneously a form of morally rational obligation (Palmer Olsen and Toddington 1999a, p. 158; Beyleveld and Brownsword 1994, pp. 352-56; Gewirth 1996, pp. 94-95, 317-18). Ultimately,

... a coherent legal idealism suggests that a rational understanding of the conception of the legal enterprise leads us to the conclusion that rules posited as laws ought to meet certain demands of morality if they are to achieve validity as laws. Legal validity, in this sense, and when ascribed to a rule or system of rules, implies a moral justification to promulgate and enforce, and consequently implies the existence of an obligation to obey. (Palmer Olsen and Toddington 1999a, p. 13)

It is the notion of morality as the legitimating criteria of legal reasoning and, hence, the rationale for the obligation to obey which is the end that Legal Idealism seeks to demonstrate.

In this paper, my focus is on outlining the background to the contemporary version of Legal Idealism, which is adopted in the course of this paper. The version of idealism adopted is that of Gewirth (1978) and Beyleveld (1991), but I do not seek to defend their argument to a supreme moral principle here. Rather, I intend to show that the difficulty that Legal Positivism has when dealing with 'hard cases' and judicial interpretive strategies is resolved by adopting a scheme of moral values in the law. In the response to the Positivist argument that moral values are incommensurate, I will show that this commensurability can be determined 'artificially' by a system of institutionalised reasoning (i.e., the law); this is to say, if I can show that the Legal Positivist argument is left incomplete without some explanation of the moral values underpinning it, I need not to show that a specific, defensible moral truth or principle is required, but rather that an artificial weighting of abstract moral principles is sufficient.

The paper will begin, in Section 2, by summarising what is understood by practical reason and the existence of different modes of practical reasoning on a continuum, this forms the basis of the understanding of both law and morality that underpins the rest of the paper. Having done so, in Section 3, I will then go on to consider the critique of the Legal Positivist's Autonomy Thesis and related ideas. On the basis of this critique, in Section 4, I will attempt to reconstruct it as a Transparent Autonomy Thesis, which, through a demonstration of commensurable moral goods, argues for the incorporation of omnilateral public morality as a justificatory line of reasoning in institutionalised or legal practical reason (Beyleveld and Brownsword 1994, p. 33). In Section 5, I will consider the problem of interpretation in a system where law and morality are separated and the Legal Positivist's claim that moral values are incommensurate. In Section 6, I will make the claim that moral goods are at the least artificially commensurable that I hold the connection between law and moral rationality necessarily exists and it is capable of surviving its transformation into institutionalised reasoning. Simply, my claim is that a system of institutionalised practical reason ought to codify how these incommensurate values will be weighted in order to offer resolution in hard cases. This forms the basis of a transparently autonomous system of institutional reasoning. This argument is significant because, if accepted, it demonstrates the necessity of incorporating, at the very least, abstract moral principles into the functioning and justification of institutionalised reasoning without the need to demonstrate that objective moral principles provide an exhaustive list of commitments. 


\section{The Continuum of Practical Reason}

In this section I will consider whether an integrated scheme of practical reasoning as existing on a continuum moving from instrumental onto prudential onto moral and, finally, onto the legal or institutionalised. I contrast lines of reasoning that hold morality to be 'private, subjective and voluntaristic' (Palmer Olsen and Toddington 1999a, p. 20), whilst the law acts as public, objective, and non-optional (Hart 1961, pp. 163-66). I suggest that morality might also be necessarily public and objective in its nature, and so seek to exclude notions of subjective, individualistic morality. This is not to say that, in portraying an opposition to this conception, law and morality are equivocal (Palmer Olsen and Toddington 1999a, pp. 20-21). Rather, it is an attempt to reinterpret and reimagine morality as something that is also capable of being public, objective, and non-optional, whilst still not maintaining the same definitional features as forms of legal, 'artificial' reasoning.

In order to understand the continuum of practical reason, it is necessary to attempt to decipher the shifts in the types of reasoning that influence our actions. To do so is to provide us with an understanding of how reasons bear upon our decisions for action. The three basic components of the continuum of practical reason are the instrumental, the prudential, and the moral; we might also add and demarcate a fourth, namely the legal (Palmer Olsen and Toddington 1999a, p. 21). At the most basic, instrumental reason is solely concerned with the (effective) employment of means in the achievement of certain given ends. Prudential reason concerns the rational employment of means to ends that are constituted by the actor or agent based upon what he or she (or it) might conceive of as valuable or in one's interests (Beyleveld 1991, p. 15).

Moral reason, finally, is concerned with those reasons for action that account for how one ought to treat others. It is often argued that moral reasons are subjectively determined, and as a result ought to be excluded from a system of legal reasoning. I will now attempt to outline both objective and subjective conceptions of moral reasoning before setting out the need to adopt the objective conception for the remainder of this paper.

Objective moral reason is concerned with the universalisation of reason based on 'how I consider I should treat others' (Palmer Olsen and Toddington 1999a, p. 22). This ought not to be construed in the highly subjectivised sense in which it is initially purveyed. Instead, it moves from prudence on the basis that it is logically unavoidable to universalise in a social context (Gewirth 1978, p. 1; Beyleveld and Brownsword 1994, pp. 24-25). Moral reason occurs when it is demonstrable that, "I ought, unconditionally or categorically, to sometimes prioritise the interests of others in the way that I act" when it appears to be contrary to my own direct interests (Gewirth 1996, p. 26). Morally rational reasons, then, are those reasons that I am obliged to follow by the categorical needs of my own prudential interest, which, once universalised, would lead me to contradiction were I to deny them to others. To demonstrate by example: if I believe that owning dogs $(x)$ is a cure for loneliness (y), it would be illogical and contradictory for me to challenge your assertion that you need a dog because you are lonely. That is, if I ought to $x$ because $x$ is a means to $y$ and $y$ is in my interest, then, equally and necessarily, if $y$ is in your interest then you ought to $x$ (Gewirth 1978). This, ' . . approach to the problem seeks to demonstrate that there are compelling practical reasons which sometimes, and in some circumstances, rationally oblige agents to subordinate or modify their prudential interests to take into account the interest of others' (Palmer Olsen and Toddington 1999a, p. 25). The claim to moral rationality ultimately rests on the intrinsic considerations of my own prudence-and the categorical necessities of that rational prudential will (Kant 1956, pp. 36-40)-which when logically universalised provides me with other-regarding reasons for curtailing my own prudential aspirations (Palmer Olsen and Toddington 1999a, p. 24). For the purposes of this paper, the claim to moral rationality is framed around Gewirth's Categorical Imperative, which requires an agent to 'Act in accord with the generic rights of your recipients as well as of yourself' (Gewirth 1978, p. 135). It is this which brings us to the inclusion of legal reason within our continuum of practical reason as the most complex form of practical reason with the continuum. As Gewirth notes, 
This type of argument ... begins from prudence and tries to show that there necessarily arises from it categorical, overriding and other-regarding reasons for action which must condition what, rationally, I take to be valid prudential reasoning. ... [T]his view seeks to portray 'other-regarding' - i.e., moral—reasoning as a related, yet distinct and superior, form of practical reasoning in that prudence modified by rationality becomes subordinate to morality. (Gewirth 1996, p. 24)

This supplies us with Gewirth's Categorical Imperative, which requires an agent to 'Act in accord with the generic rights of your recipients as well as of yourself' (Gewirth 1978, p. 135). It is at this point that we find ourselves at the conception, and supervening point, of moral rationality. It is this concept of moral rationality that is adopted henceforth, and which is, to be shown as, demonstrably connected to institutionalised adjudicative reasoning — the reasoning that is adopted by judges.

However, 'Moral' and 'morality' are used in different ways, some of which are prone to confusion, as we have already seen, where 'moral rationality' is more concise. Finnis' characterisation is instructive,

Moral thought is simply rational thought at full stretch, integrating emotions and feelings, but undeflected by them ... The fundamental principle of moral thought is simply the demand to be fully rational: in so far as it is in your power; allow nothing but the basic reasons for action to shape your practical thinking as you find, develop, and use your opportunities to pursue human flourishing through your chosen actions. (Finnis 1981, pp. 136-37)

Whilst Finnis' characterisation of morality is different from that of Gewirth, it is instructive at this juncture. Most importantly, this conception is one of objective moral principle.

Against this objective conception of morality, is the perspective that morality is a private and subjective enterprise. It is a generally accepted point that 'moral' reasoning-which I take here to mean the holding of "goods" that are based upon one's own subjective value system-ought to be excluded from the judicial and ministerial decision-making processes (Palmer Olsen and Toddington 1999a, pp. 86-87). That is, the application of the law should be based on legal principles rather than on subjective moral value judgments. This interpretation of 'Morality' is volunteered by Coleman,

If the legality of a norm depends on its substantive moral content (as opposed to its pedigree), then because the demands of morality are controversial and the source of conflict and disagreement, ordinary citizens will be unable to resolve authoritatively their doubts about what the law is or what it requires of them. (Coleman 1996, p. 292)

It would be absurd to simultaneously hold that morals are necessarily connected with the legitimacy of a legal system and the obligation to obey said system, whilst also suggesting that morality is individualist and subjective. Whilst the expression of subjective 'morality' (or, henceforth, unilateral value disparity (Kant 1996, p. 16.)) runs contrary to the lucid expression of legal principles, given its inherently paternalistic subjective viewpoint, a scheme of morally rational reasons acts to empower it. It is, 'the dialectical necessities of prudential reason [which] oblige[s] the agent to value, and thus defend, his generic capacity to act ... when universalised logically ... [this] results in the recognition of reciprocal duties to others' (Palmer Olsen and Toddington 1999b, p. 307). This separation and demarcation between "Morality" and "Moral Rationality" is expressed by Beyleveld and Brownsword,

... we hold that not only does practical reason presuppose moral reason, but an absolute moral principle as well. What would happen if we had argued instead that law must be analysed in terms of practical reason, that practical reason presupposes moral reason, but that no particular substantive moral principles can be shown to be presuppositions of moral reason? Such a position would amount to a form of moral relativism. Rational beings would be committed to adopting a moral point of view, but not to adopting any particular moral point of view. Different moral points of view would be rationally optional choices. (Beyleveld and Brownsword 1994, p. 152) 
It must be shown then, for the connection between law and morality to be a functional one, that there exists some objective morality that is separate from subjective moral viewpoints or unilateral value disparity. Moral rationality acts as a public, objective, and definitional consideration of how our prudential reasoning ought to be tailored around those other-regarding considerations that must be met by our very nature as rational agents.

Finally, Legal or Institutionalised reasoning comprises the principal use of 'exclusionary reasons', which provide a reason to refrain from acting for some other (than our own) reasons (Raz 1975, p. 487). The effect is that 'the authority's directives become our reasons' (Raz 1999, p. 193). However, working from the conception of moral rationality whereby individuals are rationally obliged to modify their own prudential on account of others, the interplay between those rational obligations to curtail one's own reasoning and the formal structure of our relations between each other becomes clearer through the imposition of exclusionary reasoning (Palmer Olsen and Toddington 1999a, p. 25). Added to this, upon the consideration of what practically rational response we might take to disagreement and uncertainty becomes clearer through the imposition of a final arbiter. That is, given the choice between an institutionalised interpretation of those morally rational concerns or a wholesale departure from them, it is through the incorporation of these general principles of practical precepts that we are to conceptualise legal reasoning.

As the workings from the instrumental to the prudential to the morally rational demonstrate, the conceptual relation between the legal and all three shows at least some connection between the law and the morally rational (MacCormick 1992, p. 130). This is on the basis that Law entails Practical Reason, which entails Moral Reason. There is, at the very least, a conceptual relationship between law and morality on the basis that both exist within the continuum of practical reason. If this is accepted and legal reasons become the fourth aspect of our continuum of 'practical reasons', it is necessary to consider whether, through the institutionalisation process, we can recognise the possibility that the application of moral rationality in the context of enforceable prescription is plausible. That is, if we can see a route from prudential reason to morally rational reason (through the process of logical universalisation, as we see in Gewirth's Categorical Imperative) and consider that it is morally rational to establish legal authority-or institutionalise the decision making and enforcement process—-then it is logically attached both at the point of ontological transformation and beyond throughout continuation. If accepted, legality ought to strive to openly aspire to the exacting standards of moral rationality and, it will be shown, be enough to premise a legitimacy criterion that provides legality with moral authority and, in turn, its participants with a moral obligation to obey. It is towards this argument that the remainder of the paper is focussed on.

\section{Critiquing the Autonomy Thesis}

This section considers the argument in favour of an autonomous conception of legality from morality, such that the latter ought not to be incorporated into the prior's system of reasoning. This is the Legal Postivist's Autonomy Thesis. It is an attempt to show that law's legitimacy and authority is separate from, and exists independently of, moral justification (Waldron 1992, p. 160). This account of law rests on the notion of the need to avoid, or remove oneself from, the unilateral value disparity (the conception of morality as subjective and individualistic) of the 'original position' (Rawls 1971) or the 'state of nature' (Hobbes 2005). It is on account of this that law must eschew morality if it is to avoid reproducing the indeterminacy and conflict of the pre-legal position. In this section, the argument for law's autonomy is deconstructed on account of this misinterpretation of the value of moral rationality and on account of its own indeterminacy within the realms of dispute resolution.

The Autonomy Thesis represents the Positivist view that law is 'autonomous' or 'separate' from morality, in that it regards law as a form of legitimate normative force that is distinct from the moral principles (Postema 1996, pp. 80-82). If an understanding of the need to initiate a social contract can be grasped, whereby we recognise that pure prudence and a lack of morality, as social co-operation (Postema 1996, pp. 91-93), plays a part in getting us in to the social contract then doubt is raised as 
to the authoritative cut-off point for moral argument. That is, if some form of moral rationality is sufficient to initiate the institutionalisation process, then why and at what point is it to be dismissed from the practical reasoning of the institution? This question is seen differently dependent on one's conception of 'morality'. If one reasons-I claim incorrectly-that morality consists in subjective viewpoints and it exists as unilateral value disparity causing a perennial state of war, pre-law then the initiation of institutionalisation is to resolve or fix that problem (Hobbes 2005, pp. 82-83). If, however, the conception maintained is one of moral rationality - for instance, to Kant's Categorical Imperative (Kant 1997, p. 421) or Gewirth's PGC (Gewirth 1978, p. 134)—and the imposition of institutionalised reasoning is on account of the need to do justice or resolve the indeterminacy of the absence of the formal structure of reasoning, then the absence of 'morality' post-incorporation appears to create a greater risk of value disparity between the system and moral reason.

The Autonomy Thesis itself is based upon three sub-theses-the Limited Domain Thesis, the Pre-Emption Thesis, and the Source Thesis (Postema 1996, p. 82). These expressly demand that law, a body of autonomous norms, operate within a limited domain of practical reason; that these norms account for exclusionary reasons for action that preclude conflicting reasons for actions, therefore pre-empting contrary preferences; and that these norms are identifiable at source without a need to resort to moral, political or social arguments or norms. This can therefore be seen as positivism's attempt to demarcate law and morality within the realm of practical reasoning; that is, to isolate law and legal discourse from morality and moral discourse. Simply, the Autonomy Thesis 'offers an account of how the introduction of law into the practical reasoning of individual agents alters it. According to the Autonomy Thesis, law adds new reasons and norms to the stock of practical considerations that are already available to agents and defines a special domain of distinctively legal reasons and norms' (Postema 1996, p. 83). This is the Limited Domain Thesis. This is supplemented by the Sources Thesis, which holds that law must be determined by reference to recognisable social facts and without recourse to moral argument (Raz 2009, pp. 45-52). Finally, the Pre-Emption Thesis holds that law's limited domain is isolated from other practical reasons by the pre-emptive or exclusionary reasons for action it provides (Raz 1999, pp. 39-40). Thus,

Legal norms not only provide rational agents with positive (first-order) reasons to act in certain ways, but they also provide them with second-order reasons for not acting on certain other reasons. These second-order, pre-emptive reasons prevail over potentially competing reasons, not by outweighing those reasons, but by precluding an agent's acting on them. (Postema 1996, p. 85)

The effect of this assertion is that we are led to note that the addressee of a norm is given practical reasons for acting in a certain ways and reasons not to consider acting otherwise. (Raz 1975, p. 35). That is, if the law is accepted as autonomous, then the addressee is given an obligation to obey, which is not based or premised upon 'subjective personal or objective natural morality' or coercive threat (Postema 1996, pp. 82-83).

The Autonomy Thesis focuses upon the aspiration to or achievement of secure and determinate criteria of justice, whereby individuals are provided with 'artificial' and publicly accessible norms that ought to be followed (Hart 2012, pp. 20-24). Relationally then, too, the institution must be given the authority to overrule-create, enforce, and maintain norms - the individualised moral or value judgments of the 'addressees'. The claim of the Positivist's then is that it is because of the subjective morality or value-pluralism and the complexity of social groups to which the creation of a set of codified and institutionalised norms, law, seeks to address (Hobbes 2005, p. 97). Accordingly, it is the destabilising indeterminacy of morality (or, here, 'unilateral value disparity') itself that bases the need for law and justifies the detachment and, in this regard, necessary (or desirable) disconnect between law and morality. It is the need for social co-ordination that acts as the criteria for law's legitimacy (Postema 1996, p. 93).

It is now necessary to return to the dispute between interpretations of 'morality' that situate it as either some form of unilateral value disparity or as the reasoning of moral rationality. This represents 
the crux of the dispute at hand. For the caution to tying legality to morality, if there can be no agreement as to what is represented by morality, appears to be the best option (Radbruch 1950, p. 116). That is, if morality only exists subjectively then the law ought to act autonomously of its will. Simply, 'there may be disagreement both as to the appropriate moral standards and as to the required points of conformity' (Hart 2012, p. 205). If so, and legality is concerned with stability and predictability (Raz 2009, pp. 49-50; Coleman 1996, p. 296), then it would appear irrational to base the validity of law on such fragile and instable concerns (Palmer Olsen and Toddington 1999a, p. 36). This, however, only holds true if we conceive of morality as unilateral value disparity. If, rather, we are concerned by those morally rational principles that direct our behaviours on account of others because of our agency, then what is involved is an objective assessment of good (Beyleveld and Brownsword 1994, pp. 23-25). This omnilateral public morality is then surely a direction to do 'our moral best' (Palmer Olsen and Toddington 1999a, p. 38) in the weighing of conflicting interests and the interpretation of those relevant legal principles so as to give a coherent account of underlying, inherent, and objective 'good'. Simply, if there are objective moral truths or principles, then it would be incoherent for legal reasoning to act autonomously of it.

In vying for a separated system, the Positivist account of the Autonomy Thesis maintains that, on occasion, 'what is law' must prevail over 'what is just'. (Radbruch 1950, p. 117) As such, adjudication must prioritise certainty over any other values (Palmer Olsen and Toddington 1999a, p. 40). This, however, assumes that it is contingently possible to account for all conflicts by reference to 'what is law' alone, a position that is challenged by the existence of 'hard cases' to which this paper will return to in Section 5. (Postema 1996, p. 94). Given that the starting point for the claim that the law necessarily exists by reason of the unilateral value disparity, then the law is also necessarily the result of moral phenomenon and its complete severance cannot be made (Hart 2012, p. 206). That is, the problem for which justified the creation of institutionalised reasoning was unilateral value disparity. As such, institutionalised reasoning must mirror the disparate values which justify it. To put it another way, if the morality cannot settle its conflict, then the law must create structured norms in its place. However, this still cannot account for the complete separation of law and morality. The law must continue to reflect the moral phenomena in its search for certainty.

However, under the Legal Positivist model, in the search for certainty the law must appeal to technical validity - the notion that law is valid because it adheres to some procedural requirements as identified by the system itself; that is, a law is valid because it passes through the agreed upon channels, regardless of its moral content. On this account, the law's validity and therein the obligation to obey are removed from the continuum of practical reason and then sealed off as purely procedural. Technical validity is thus arguably an arbitrary and empty conception of validity (Hart 2012, pp. 102-3). In the absence of moral validity, law is to be validated by reference to those rules that are in place to determine the manner in which new law is made (Coleman 1996, p. 292). This is so, if, as Hart (2012, pp. 100-4, 250-51) claims, the law has adhered to the 'rule of recognition'. However, if law's validity is purely technical, and in that way demarcated from the obligation to obey it, for it provides exclusionary reasons for action, this undermines the justification for the authority to rule (Palmer Olsen and Toddington 1999a, p. 44). That is, there is an implication that legal rules provide guidance to practical reason, but these become absent of normative force where the concept of validity is purely technical and hence separated from the issue of an obligation to obey (Finnis 1996, p. 203). As Fuller (1958, p. 656) has noted, '[t]his obligation seems ... wholly unrelated to any of the ordinary, extra-legal ends of human life ... [That] law must be strictly severed from morality ... seems to deny the possibility of any bridge between the obligation to obey law and other moral obligations'. If, however we reframe the question in line with the conception of moral rationality as leading to institutionalisation for the purpose of securing those reasons required by it. In this construction, the notion of procedure is equally relevant to a legal system that is built out of rational morality and it makes good sense to incorporate procedural validity (Beyleveld and Brownsword 2006). After all, if justice requires the institution of an arbiter to settle disputes, then the security of moral rights ought surely to maintain some form of rational procedure? If this is so, then immediately we can see that technical validity is also a relevant 
condition of a connected system, as it is in a disconnected system where the problems of legitimacy are beginning to become apparent.

It might be supposed, however, that technical, procedural validity is sufficient for us to accept that, in turn, an obligation to obey exists. Does this not then face the same questions as posed by Raz, ' ... how could it be that the say-so of one person constitutes a reason, a duty, for another? Is it that easy to manufacture duties out of thin air?' (Raz 2006, p. 1012) In the face of this, there surely must be some conception of functional necessity to an overall social goal (Palmer Olsen and Toddington 1999a, p. 45). There must then be a justificatory reason; a reason that would be valid independently of the procedural requirements comprising the validity of some authority (Finnis 1996, p. 204).

Ostensibly, this notion of technical legal validity rests on the conception of 'law as a product'. As Postema recognises, 'Law, as the Autonomy Thesis conceives it, is not essentially involved in this process, it is a product of it' (Postema 1996, p. 110). Van der Burg (1999, pp. 63-66) presents two visualisations of the law; 'law as a practice' and 'law as a product'. The 'practice' model focuses on how the law is interpreted and applied in order to shape it, whilst the 'product' model is concerned with how the law is constructed as a body of norms. It is the appeal to legitimation of the products of a legal system that is sought by technical legal validity when we encounter an expression to 'the observation of proper procedures' (MacCormick 1996). Whilst, 'law in the books' (Van der Burg 1999, p. 65) is of relevance to us, as an authoritative reason, it does not help in settling the issues of interpretation (Postema 1996, p. 110). The law must therefore be imagined as a combination of both 'practice' and 'product' to ensure that those justificatory reasons for the law's legitimacy to act are enabled to 'shine through' in the production of norms (Palmer Olsen and Toddington 1999a, p. 116). That is, whilst technical validity might be sufficient to explain the legitimacy of the law's products, it fails to provide the same legitimacy for the law's practices.

It is the existence of this problem that justifies a departure from the reasoning behind the Positivistic view to the Idealistic view point that I seek to maintain in this paper. To do so, it is necessary to adapt the Autonomy Thesis to one that is capable of accounting for those situations where judges decide the law but do not reason according to the law. This, it is suggested, accounts for both the practice of law as well as the products of law. It is the absence of the requisite 'openness' for these interpretative and justificatory concerns, which, as Postema highlights, is further limited when judges are unable to reason according to the law,

... adjudicative institutions are authorised to settle issues left unsettled by the set of source-based legal norms available at any point in time. They are authorised to add to or alter the norms of law. Since, in such cases, by hypothesis, the existing legal considerations are silent, indeterminate, or in conflict, the courts' setting of them is determined not by appeal to the law, but by appeals to considerations outside its limited domain. (Postema 1996, p. 93)

Therefore, the logic of the Autonomy Thesis must be expanded to encompass this problem, it must be articulated in a way that informs the interpretative strategies of the adjudicative institutions in respect of the pre-emptive aims that justify the Autonomy Thesis itself (Postema 1996, p. 110). The Autonomy Thesis here becomes the Institutionalised Autonomy Thesis-the version of the Autonomy Thesis situated within the context of adjudicative (law-applying) institutions-which requires an elucidation of the interpretive strategies of the adjudication process (Postema 1996, pp. 93-94). This is to shift our focus from that of a broad understanding of law as norm creation to one where adjudicative institutions are authorised to settle matters thatare left unsettled by the source-based legal norms (Postema 1996, p. 93). To this end, we must embrace a broad conception of the functional aspects of legal reason (Postema 1996, pp. 110-11): that moral rationality can be best secured through its incorporation in an 'artificial' structure of reasoning that is established to overrule unilateral value disparity by setting objective, omnilateral public morality, and does so by the manifestation of authoritative underpinnings (Palmer Olsen and Toddington 1999a, p. 113). By this authoritative manifestation, it justifiably seeks to overrule the individualised practical reasoning of those participants (citizens) and actors (officials) who have a correlative obligation to obey and, in this way, becomes autonomous. 
Returning to the Autonomy Thesis, we find that the logic of its reasoning is threatened, by the demarcation between legal norms that are supposedly autonomous of political morality and the interpretation of those norms that are to rely on non-legal, and hence non-autonomous, reasons for such interpretations. From here, unless we are to qualify or abandon the Autonomy Thesis, we must attempt to explain '[the] institutionalisation not just of autonomous norms, but of autonomous interpretations of norms, signals a crucial complexity in the idea of autonomous normativity' (Palmer Olsen and Toddington 1999b, p. 297). Can we circumvent the need for such a complex theory by appealing instead to moral rationality to supply us with the justifications that are needed to guide interpretation when it falls outside of legal argumentation? Postema suggests we,

... should look for a model which integrates arguments of political morality into proper legal argument and justification, starting from recognition of the reflectively self-critical character of legal practice... Justification within such a practice can proceed despite differing strategies of reasoning, and will involve not only justifying that particular result, but also justifying the way one reaches that result to those who reason differently. (Postema 1996, p. 111)

This requires the reconstruction of both the Autonomy Thesis and the Institutionalised Autonomy Thesis as a transparently autonomous system of reason, which this paper must now turn.

\section{Constructing a Transparent Autonomy Thesis}

This section seeks to justify reconstructing the argument as one of transparent autonomy. A model that better explains the legitimate function of institutionalised reasoning. In order to do so, I begin by considering the notion of interpretation and adjudication that was found to have caused so many problems for the Autonomy Thesis, in so doing I consider the lines of reasoning necessary in a transparently autonomous system. I will do this by adopting a Hobbesian version of the argument to the social contract in order to demonstrate the shortfalls of the 'pure' Autonomy Thesis. The aim of which is to consider whether a more substantive justification for an institution's continued claim to legitimacy can be made beyond the appeal to technical validity and the prudential will to avoid the state of nature.

If we accept that both the Autonomy Thesis and the Institutionalised Autonomy Thesis presuppose that a move exists from the 'pre-legal' to the 'legal', then we find that a social contract theory is equivocal in its stages of argument to that of the completion of the Institutionalised Autonomy Theory. These stages are conceived, as follows (Palmer Olsen and Toddington 1999a, pp. 124-25):

i. No Law/Pre-Law_'Acknowledgement of the intolerable condition of pre-legality'.

ii. Legal Incorporation-'A subsequent act of incorporation'.

iii. Law's Autonomy_-The strategy of autonomy' or 'establishment of the terms and principles of the trusteeship (or sovereignty) of the powers resulting from incorporation'.

iv. Institutionalised Autonomy Theory of Adjudication- The problem of settling the criteria of valid interpretation and application of positive law in relation to the principles so established'.

The task is principally to consider the passing through of the above stages in an attempt to complete the Institutionalised Autonomy theory. This, as Postema claims, is to offer,

A theory of law which must give an account of how legal norms operate in the practical reasoning of those whom they govern. In view of the complex interdependence between the practical reasoning in courts and outside them, if source-based norms play an important role in the practical reasoning of both officials and citizens, then so too must non-source-based considerations. (Postema 1996, pp. 110-11)

The problem is that, if, in the state of nature, the conflict and normative uncertainty is such as to lead us to the logic of autonomy - or institutionalisation — as found in the bare version of the Autonomy Thesis, and we are then forced to question that autonomy when reliance on the original principles behind 
incorporation are relied upon in the interpretation of positive laws. To put it another way, if we take the Hobbesian version of the contract as our primary example (Hobbes 2005, pp. 115-19), then we note that the 'state of nature' is conceived of as a place of misery and perennial war given that individuals are inherently motivated by concerns for self (Hobbes 2005, pp. 82-83, 115) but, as empowered by rational thought, are capable of conceiving means to end that 'state of war' by institutionalisation through a social contract and the creation of a sovereign (Hobbes 2005, pp. 119-28). Simply, we find Hobbes' transition from stage (i) to (ii) to be based upon 'prudential' practical reasons (Hobbes 2005, p. 117). As Gauthier notes,

... in order to escape from the state of nature (or to avoid being in it) each person judges it individually rational for her to live under a sovereign. Indeed, finding the state of nature to be a "no-win" situation, each person clamors, as Hampton says, to create a "winner", "an absolute master over all things", who can afford her peace and security. (Gauthier 1987, p. 290)

That is, each individual's rational prudential reasoning gives a valid reason for moving out of the state of nature, the logic of which might be extended across all individuals that are capable of rational reasoning. At stage (iii), we seek to elucidate some form of valid legitimacy criteria. The form of which, under the Autonomy Thesis, appears to offer little more than an interpretation of formal or procedural legitimacy, such as to offer the minimal imposition of what we are to call 'law'. For Hobbes (2005, pp. 120-22), the 'covenant' is legitimised on the basis that to leave the 'commonwealth' is to return to the state of war. This suggests that, whether consent has actually been given or not, the prudential reasons for avoiding the state of war are sufficient in grounding legitimacy universally (Hobbes 2005, p. 122). However, this is surely to be insufficient for the sacrifice of power post-incorporation; rather, we might argue that, 'The logic of autonomy in stage (iii) from any perspective must then contain sufficient provision for the identification of a finite range of possibly acceptable claims to reasonable interpretations of the foundational principles' (Palmer Olsen and Toddington 1999a, p. 128). The essence of stage (iii) is to establish some objective criteria for the reasonable use of the power which has been conveyed in stage (ii); it is, simply, the notion that the power should not be used arbitrarily (Palmer Olsen and Toddington 1999a, p. 127). It is for this reason that purely formal or procedural legitimacy criteria fail to properly maintain the strategy of autonomy and, ultimately, provide a conception of what is a reasonable exercise of institutionalised reasoning.

If, then, we are to find a route from stage (iii) into a Legal Idealist vision of stage (iv), then we ought to consider what may be encompassed as capable of solving the problem of interpretation. On the basis of this shift, from Autonomy Thesis to Institutionalised Autonomy Thesis and the attempt to complete the Institutionalised Autonomy Theory, (Postema 1996, p. 110), we might begin by recognising the struggle that is inherent between law and political morality, and this struggle may lead us to accept the need to institute some form of 'artificial' reasoning or autonomy, but qualify this by seeking instead to adhere to transparent autonomy (Palmer Olsen and Toddington 1999a, p. 115). This is defined as 'a form of autonomy that allows the law's background considerations and justifications to shine through and illuminate the processes of interpretation and application' (Palmer Olsen and Toddington 1999a, p. 116). That is, if the law is envisaged as being autonomous from moral rationality, in the sense that it ought not to affect the reasoning, say, of those applying the law where to do so would pose a risk that the subjective values of the applicator may alter the modelling of those rights being considered in the individual case (Dworkin 1997, pp. 90-94). As part of the justificatory regime, we must 'integrate arguments of political morality into proper legal argument' (Postema 1996, p. 111), and in such a manner, 'we must admit ex hypothesi that the principle in question must at least furnish a criterion to enable us to determine that some conceptions of the implications of practical reason are reasonable and some are not' (Palmer Olsen and Toddington 1999b, p. 305). My claim, then, is that moral rationality ought to hold a position behind the system as a whole, whereby its influence to certain 'goods' or 'values' for that system operate as considerations for the application of rights and the justifications for 
the institution itself. ${ }^{1}$ This is the end point that we must reach in the coming sections. The task of this paper then is to elucidate what reasonable use of moral rationality may be justified within a scheme of transparently autonomous law. This is to logically expand from the idea that there is enough practical rationality to get us into the Autonomy Thesis or incorporation stage, then there ought to be enough to complete the Institutionalised Autonomy theory and reach stage (iv).

At a foundational level, the argument is that legal legitimacy is, and ought to be, based upon the attempt to apply a set of norms that remains in touch with moral rationality, such that it is capable of reacting to and pre-empting the problems that are associated with regulation and co-ordination in a complex society. As Beyleveld and Brownsword note,

Having argued that law is an affair of practical reason, and that practical reason presupposes Moral Reason-indeed, that it presupposes ... [Gewirth's Categorical Imperative]—this neutrality is no longer sustainable: the ideal-typical case of the Legal Enterprise is where this enterprise is Morally legitimate, and, according to our specific argument, Moral legitimacy is to be judged using criteria which employ ... [Gewirth's Categorical Imperative] as the supreme moral/legal principle. (Beyleveld and Brownsword 1994, p. 164, original emphasis)

It is not enough to base our conception of validity solely on form, in the Positivist sense, and instead we must-given that morality initiates the move from the state of nature to institutionalised reasoning in the first place-demonstrate that legal validity is essentially based upon moral rationality (Beyleveld and Brownsword 1994, p. 131). To put it another way, our concerns for 'equality', 'justice', 'fairness', the 'Rule of Law', and so forth are the very expressions of the law's relation to moral rationality (Postema 1996, p. 93; Dworkin 1998, p. 214) and, indeed, they arise out of our need to conform to Gewirth's Categorical Imperative. This approach, it will be seen, is consistent with Dworkin's characterisation that the law is represented by a combination of rules and moral principles that operate behind those rules, which act as a means of interpreting those rules; or the representation of Law as Integrity (Dworkin 1998, chp. 7).

\section{Interpretation and Incommensurability}

I now return to the incorporation of interpretation in the process of adjudication of legal disputes; that is, the move to stage (iv). I will, in this section, turn to some arguments against the commensurability of moral value - on the grounds of its absent agreement or objectivity. In response to this claim, I seek to demonstrate that morally rational reasoning is perfectly able to offer a commensurate, and even hierarchical, scheme for the weighting of individual's claims or interests, such that it is capable of shining through and elucidating those interpretative and justificatory concerns that are posed by the Autonomy Thesis. To do so, I will begin by considering the notion of the 'hard case' and the means by which we are to resolve and offer solutions against the contentious moral and legal backdrop that these cases inherently concern. In so doing, it is necessary to consider the pervasiveness to this idea of Dworkin's notion of the right answer and the lines of reasoning that demonstrate the necessary connection between law and moral rationality. This line of reasoning is adopted but is developed further with Beyleveld and Brownsword (1994, p. 436) conception of the thesis as a model of attempt, rather than achievement, as a framework for legal adjudication. However, this poses a further challenge to the connected system; namely, the assertion that moral values are 'incommensurable' and are incapable of being ascribed a hierarchical scheme. Whilst this notion of commensurability remains throughout this section, it must be initially be challenged against the right answer thesis.

Interpretation in legal reasoning is apparent in both 'factual' and 'normative' stages; in the prior, we find that, for judges to make decisions, we are less concerned by literal facts and instead find our attentions drawn to statements of facts (Palmer Olsen and Toddington 1999a, p. 132). This is not to 
deceive necessarily, rather it is to create of view, for legal purposes, of the 'event' that allows it to be 'filed' or fit into a format that is capable of being processed by the system. This is because of laws' construction of an 'artificial' reality through the use of norms. By shaping and ordering laws' reality in relation to social practices that might not 'fit' perfectly, we find that it becomes laden with value. However, how are we to evaluate the judgements and decisions taken by our legal system? Or, to put it another way, how do we know that the decision taken is the right one? (Postema 1996, pp. 110-11) It is simply, 'The formal answer is that it should be based on a coherent and accessible scheme of practical rationality capable of incorporating both the substantive and procedural aspects of the problem of legitimacy' (Palmer Olsen and Toddington 1999a, p. 133). In searching for that answer, those charged with the power to make decisions are not entitled to balance the potential outcomes, but instead they are responsible for making the right decision (Dworkin 1998, p. 218). This is Dworkin's right answer thesis, which, ' . . . is simply the terminus of the view that the more knowledge one has about the dynamic relations between values and policies, the better one's decisions based upon weighing and balancing them would be' (Toddington 2013, p. 40). On this basis, our intuitive consideration that those empowered with decision making in the adjudication process are charged with not simply making $a$ decision but making the correct decision. It is with a conception of what the relevant criteria are for determining what the correct answer is that we are able to concisely explain what grounds are relevant to the process.

These are particularly problematic for law's so called 'hard cases'; those in which a legal answer is controversial and troublesome because of the contentious moral backdrop or because the law itself is silent on the issue. ${ }^{2}$ For Dworkin, legal reasoning - in the form of decision making-is premised upon two separate considerations (Dworkin 1998, pp. 228-32). First, the empirical notion of 'fit' —alluded to above-where, while taking account of surrounding provisions, the decision maker is obliged to consider and account for the general direction of the law as a whole and conform the decision in the present case to the existing provisions (Dworkin 1998, pp. 230, 255). Second, the dimension that is aligned with moral rationality as 'justification' (Dworkin 1998, pp. 231, 255). It is in the balancing and weighing of these lines of reasoning that allow for the decision maker to search for-and, preferably, find-the right answer (Dworkin 1977). As Dworkin notes, 'They are entitled, in principle, to have their acts and affairs judged in accordance with the best view of what the legal standards of the community required or permitted at the time they acted, and integrity demands that these standards be as coherent, as the state speaking with a single voice' (Dworkin 1998, p. 218). It is the search, in essence, for a decision which will make the whole system coherent (Dworkin 1998, p. 245). Dworkin himself cites both McLoughlin v O'Brian ${ }^{3}$ (Dworkin 1998, pp. 240-60) and Spartan Steel ${ }^{4}$ (Dworkin 1997, pp. 83-85) as examples of the scope of the method. ${ }^{5}$ A decision of this kind will be one that can be seen as identifiable in the existing legal provisions and rendered morally sound.

The right answer in a case will be the one in which the entirety of the existing legal material is identified and interpreted in a way that would make the decision morally sound. Whilst the demarcation within this theory of adjudication between common law reasoning and statutory interpretation is not necessary for present purposes, it should be noted that Dworkin advocates for adopting the Herculean method for both the common law and statute (Dworkin 1998, chp. 9). ${ }^{6}$ Such a distinction is not necessary given that the rules of interpretation are themselves in need of interpretation. The selection of a method of interpreting the concerned statute will likely determine the result of the interpretive process; that is, the perceived intention of the legislature is subject to the

Consider, for example, the case of Donoghue v Stevenson [1932] A.C. 652.

McLoughlin v O'Brian [1983] 1 AC 410.

Spartan Steel \& Alloys Ltd v Martin \& Co (Contractors) Ltd [1973] 1 QB 27.

See also: Lord Steyn's judgement in Chester v Afshar [2004] UKHL 41, para. 18-25.

The content of the 'existing legal material' required for identification and interpretation is likely to be different; that is, hard cases deriving from statute may include considerations of legislative intent as well as the legislation itself. 
rule of interpretation adopted (Palmer Olsen and Toddington 1999a, p. 134). The problem with this is in deciding which of the rules of interpretation ought to be selected; the criteria for selecting one interpretation over another must, at some point, be authoritatively chosen, which brings us back to the dilemma of the 'hard case'. There must be some reason for selecting one interpretation over another; it is this void that the Herculean method seeks to fill.

The pressing issue to consider at this juncture is the claim to the 'incommensurability of values', the reasoning of which can be briefly summarised. Essentially, this paper notes that practical reason takes us beyond prudence as mere self-interest. However, having stepped beyond this point we find, it is claimed, that 'moral goods' represent for us a complex matrix to which no hierarchical scheme can be subscribed (Palmer Olsen and Toddington 1999a, p. 138). As such, law is requisitely authoritative because it allows for the pursuit of multi-dimensional good to be achieved (Finnis 1996, pp. 202-3). This, for Finnis, is the justification behind law's authority and the obligation to obey; simply because it is a means by which we can pursue 'goods' (Finnis 1984). The effect of this is that, ultimately, if 'goods' are incommensurable, and no scheme of hierarchy can be ascertained then the search for the right answer-in any conception of the thesis-is futile and doomed to be ineffective. Its relevance then is only apparent if it can be shown that some hierarchical system or structure can be attained to those moral 'goods'. That is, if moral 'goods' are deemed to be incommensurate-because they are nothing more than disparate unilateral values—-the justification for the law's autonomy rests on this very incommensurability.

Whilst Finnis asserts that these values are incommensurable (Finnis 1984, pp. 143-44) and doubt might remain as to what the right answer is in a particular case (Finnis 1984, p. 145), this does not justify that it is (a) implausible that a balance could be struck between the two lines of reasoning or that (b) an attempt should not be made to situate our decisions (or choices) in 'hard cases' as best as we can-knowing the fallibility of humans in the eclipsing shadow of Hercules J (Dworkin 1998, p. 245). Further still, we are alerted to a logical shift in our focus if we follow Finnis' line of reasoning to its conclusion. That is, if those values or lines of reasoning truly are incommensurable, then we are no longer talking about a 'hard case', but instead we have on our hands an impossible case-for there is no plausible method of settling the conflict (Finnis 1981, p. 146). If this is so, then it is necessary to question the legitimacy of the legal system to which legitimacy is sought. For, if 'a decision with any pretensions to authoritative status in relation to a correlative obligation to obey ... [then it] must, at least ostensibly, be a reasoned resolution of a social conflict' (Palmer Olsen and Toddington 1999a, p. 142). If the values are truly held to be incommensurable, then the result is no better settled than by a flip of a coin.

Equally, the Herculean strategy may not seem to encapsulate a 'choice' at all if there is only one answer at the end of it (Finnis 1984, p. 146) — this is no longer choice, but simply a stone turning exercise. What then if one reasons that it is the innate imperfections of human reasoning and possibility of unilateral value disparity which make these decisions difficult? In this light, it might be suggested that there is a choice to be made and it is not that values are incommensurable - this is to recognise that, whilst humans hold imperfections, they are simply striving to situate their selves in the best possible account of law as an element of practical reasoning (Palmer Olsen and Toddington 1999a, p. 143). As Pattinson (2002, p. 169) notes, in 'an ideal world where supremely rational agents ... [would] universally seek to uphold ... [goods] without problems of scarcity' but this is not realistic. The right answer thesis-characterized in this way-is less a blind aspiration to perfection or utopia than it is to the improvement and fulfilment of legal reasoning as a logical extension of the scheme of practical reasoning (in that it is 'artificial') under recognised imperfect conditions (Dworkin 1998, p. 188). Given this fallibility, it is also recognisable that some decisions that were made within a system of this type will on occasion get it wrong. It may then be necessary to correct these errors. As Beyleveld and Brownsword note,

Although Hercules is presented as superhuman and, no doubt, as one who unfailingly comes up with the right answer, we can read the concept of a Judge implicit in this as one who attempts sincerely and seriously to emulate Hercules. In other words, we do not need to 
worry about Hercules as a model of achievement; we can treat the concept of a Judge under the Rights Thesis, as under our own view, as essentially a model of attempt. (Beyleveld and Brownsword 1994, p. 436)

With this illumination, the balance to be struck is one that must account for the existing legal conditions primarily through empirical observation-the reasoning of 'fit'-and the aspiration to ensure an elucidation and coherence to those pre-existing legal conditions to ensure that the decision is one supported by the moral rationality that supports the framework of 'artificial' reasoning of the Autonomy Thesis-the reasoning of 'justification' (Dworkin 1998, p. 255). As Olsen and Toddington argue,

From this perspective, the dimensions of 'fit' and 'justification', rather than being two parallel lines, are seen to have a common point of departure. The reason a case presents itself as a hard case is that the existing legal material presents itself as less than morally rational, because previous authorities (legislators, judges, etc.) have acted with less insight or resources (morally or empirically) than are available in the case at hand. It is this, rather than an insoluble conflict of values, that makes the case a hard one. (Palmer Olsen and Toddington 1999a, pp. 143-44)

Fundamentally, this is to recognise the imperfection in humanity and in an artificial scheme of practical reason-the need for which, after all, is premised on those imperfections-but this does not and ought not be imposed upon the authority of a legal system when the decisions that are made, and the forms of regulation created are imperfect. This leads us to a point that was raised earlier in this section but with a clearer view. The Autonomy Thesis suffers from a fatal flaw when the reasons used to institute its creation in the first place-through incorporation-are later overlooked in order to propound autonomy (Beyleveld and Brownsword 1994, p. 435). It is those imperfections that impede the use of a Herculean autonomy from moral rationality-in the absence of such, we must resort instead to a form of autonomy that incorporates those imperfections and leads us to aspire for more (Dworkin 1998, p. 409); namely transparent autonomy.

My task is not to show that this balance will always be achieved optimally, but that we are able and concern to try. I found that stage (iv) of the argument for autonomy was an impediment to the completion of the Institutionalised Autonomy Theory unless it is possible to devise some scheme for the considerations that interpretations should take account of (Postema 1996, p. 110)-in the absence of such, we find ourselves at an impasse, if law is to be authoritative in the scheme of practical reasoning it must (as part of the pursuit of good) respond to the practically reasonable priorities of value where they are apparent, the system then is an unreasonable authority from moral rationality (Palmer Olsen and Toddington 1999a, p. 147). It must then be questioned whether some schema for the order of 'goods' - which the law is pursuing — such that our interpretations are aided and therein the authority upon which the law rests is reinforced, 'especially when that very claim lays the foundation upon which rests the separation of law's authority from moral validity' (Palmer Olsen and Toddington 1999a, p. 148). My claim at the outset of this paper was to show that a system of institutionalised practical reason ought to codify how these incommensurate values will be weighted in order to offer resolution in hard cases. For the purpose of this paper, I do not intend to show the commensurability of these values; instead, I seek to show that, at the very least, abstract moral principles into the functioning and justification of institutionalised reasoning without the need to demonstrate that objective moral principles provide an exhaustive list of commitments. It is this final step to which I now turn.

\section{Artificial Weighting in Artificial Reasoning}

Given the need to find resolution as to what is required for the justification-for both the system's use of power and within the adjudication process-and, in the face of an assertion to Dworkin's appeal to finding the right answer, the claim that these values to which we strive for justification through are, alas, incommensurable and therefore incapable of achieving the status that we require (Finnis 1984, 
p. 146). We must therefore seek to demonstrate, either, that these values are indeed commensurable and an inherent hierarchy of value exists, or that we could, at least, incorporate an 'artificial' scheme for weighting these incommensurable values, such that they become commensurable (Beyleveld and Brownsword 1994, p. 154). That is, if a multiplicity of 'good' exists for which, as Finnis claims, the law's authority is ingrained in the attempt to pursue these, then it is necessary to actively create and fix a schema that allows the artificial determination of reasonability. This is surely preferable to the absence of any coherent attempt to balance between competing concerns, interests, or goods.

Is it possible, then, to conceive such a schema which would allow us to assess the weight of those morally rational claims which gave rise to the incorporation and institutionalisation of practical reason in the first place? Jansen notes, 'In public discourse weight assessment criteria determine the weights of freestanding justified principles. They express what is important for public morality and therefore what 'counts' in freestanding discourse. They thereby assess the validity of moral norms' (Jansen 1998, p. 12). Subsequently, we might say, if we are to accept that values are indeed incommensurable, then are we not able to artificially relate them to one another, thereby installing some means by which we are to create a system for them to be made commensurate for the purpose of our artificial institutionalised reasoning; that is, the Institutionalised Autonomy Theory. Jansen continues, '[as] weight assessment criteria are categorically different, they may run counter to each other. They therefore require a principled structure which enables varying weight assignment criteria to be taken into account simultaneously' (Jansen 1998, p. 13). It is in the creation of even 'artificial' criteria for weighting these values that we supply the justification for the exercise of power; rather than claiming justification in the absence of reason.

This provides us with at least some criteria for the evaluation of 'justifiability' in the sense of morally rational concerns that are relevant to the decision making process in law. At the very least, we now have a scheme of practical reason, whereby we are able to envisage the continued relationship between the legal and the morally rational. This method of solving the problems of value pluralism - the problem to which Legal Positivism's Autonomy Thesis responds-does not make striking an artificial balance between moral goods arbitrary, nor does it disconnect the legal from the moral. Rather, I suggest that it provides a basis for which those moral concerns underpinning a political morality might be incorporated into and systematically weighed within legal reasoning. As Postema argues, rather than excluding considerations of 'justice, liberty, general community welfare, the common good, individual well-being and the like' (Postema 1996, p. 93) from the practices and processes of law, we are able to measure the pursuit of these aims. This can be seen through the law's adoption of various moral goods and the pursuit of these in modern legal reasoning and discourse. The value of which has been aptly noted by Toulson LJ,

Open justice. The words express a principle at the heart of our system of justice and vital to the rule of law. The rule of law is a fine concept but fine words butter no parsnips. How is the rule of law itself to be policed? It is an age old question. Quis custodiet ipsos custodies-who will guard the guards themselves? In a democracy, where power depends on the consent of the people governed, the answer must lie in the transparency of the legal process. Open justice lets in the light and allows the public to scrutinise the workings of the law, for better or for worse. ${ }^{7}$

In this way, the law 'integrates arguments of political morality into proper legal argument and justification' (Postema 1996, p. 111) and it is framed around a theory that recognises the need for disputes to be both settled and settled justly, In so doing, we recognise the collective need to institutionalise Kant (1996) unilateral moral will, into an omnilateral public morality acceptable to all (Toddington 2006, p. 228). Given that,

$7 \quad R$ (Guardian News and Media) v City of Westminster Magistrates' Court [2012] EWCA Civ 420, para. 1. 
... there might be enough morality to get us into the social contract (or the Autonomy Thesis), but once we are in, practical reasons which are exclusionary reasons must appeal to the logic of autonomy and not morality. However, as Postema demonstrates, there is no logic of autonomy until we fill the substantive lacuna of the [Institutionalised Autonomy Theory]. (Palmer Olsen and Toddington 1999b, p. 308, original emphasis)

It has been shown that some form of autonomy is sustainable to the point of completion provided; we base this on the interplay between the realms of practical reasons. This then is a demand that the form of autonomy necessary for legal authority is transparent, such that public morality is the source of justification for the law's continued legitimacy

\section{Conclusions}

This paper has intended to set out the beginnings of the argument to Legal Idealism and a thesis that holds that law and (rational) morality are necessarily connected. This has been done through the introduction of considerations of practical reason and the continuum on which the instrumental, prudential, moral, and institutional exist.

The notion of the autonomy of law was the starting point for the ideas regarding the role of morality and the aims of a theory of legal idealism. As we have seen, Postema's (1996) attempt to establish the 'pure' autonomy thesis and the critique of the Limited Domain raised forthwith forces us to attempt to integrate political morality into legal reasoning. However, up until this point, the argument has been made that, in the absence of some justificatory, and, hence, legitimating criteria, the Autonomy Thesis suffers a fatal flaw. It offers an incomplete explanation of legal relations and it is incapable of offering answers to questions concerned with how hard cases might be resolved. In view of these justificatory and legitimating grounds, I have sought to demonstrate that, at the very least, the argument that moral justifications ought to be ascribed artificial weight (if they are thought to be incommensurable) within artificial reasoning. Simply, an institution ought to codify how these incommensurable values will be weighed in order to offer resolution of hard cases. In its absence, we are left with an Autonomy Thesis that does not explain the failure to consider the reasoning for institutionalisation post-incorporation. However, a full argument to the objectivity of moral reason may show that such values are commensurate; this was, alas, beyond the scope of this paper.

In essence, Legal Idealism is concerned with both the structures and procedures of institutionalised practical reasoning, but, especially, with the notion of the 'final arbiter'. The autonomy of law must be admitted as an organised system of reasoning different from political morality as an attempt to allow moral reasoning to function in a viable and justifiable way. The obligation to be under the system is, then, an implication of morality itself. However, morality cannot be reinstated as a final arbiter-this would merely reproduce the regulatory problem of Kant's 'unilateral moral will' (Kant 1996). Morality itself must become 'omnilateral' and establish the Self as the basis in public reason (Palmer Olsen and Toddington 1999a, p. 34). The key is to allow for morality to shine through the artificial reasoning of the law. In this way, the seeming paradox between legal reasoning and moral reasoning is overcome. The aim of a legitimate legal order is to strive to do justice in the faith that moral reasoners invest when subordinating selves to legality. This is what is meant by 'legal idealism' and transparent autonomy.

Funding: This research received no external funding.

Acknowledgments: Thanks to Lisa Webley, Stuart Toddington, Claire-Michelle Smyth and the anonymous reviewers for their comments on earlier drafts.

Conflicts of Interest: The author declares no conflict of interest.

\section{References}

Beyleveld, Deryck. 1991. The Dialectical Necessity of Morality: An Analysis and Defense of Alan Gewirth's Argument to the Principle of Generic Consistency. Chicago: University of Chicago Press.

Beyleveld, Deryck, and Roger Brownsword. 1994. Law as a Moral Judgment. Sheffield: Sheffield Academic Press. 
Beyleveld, Deryck, and Roger Brownsword. 2006. Principle, Proceduralism, and Precaution in a Community of Rights. Ratio Juris 19: 141-68. [CrossRef]

Coleman, Jules. 1996. Authority and Reason. In The Autonomy of Law. Edited by Robert George. Oxford: Claredon Press, pp. 289-320.

Dworkin, Ronald. 1977. No Right Answer. In Law, Morality, and Society: Essays in Honour of HLA Hart. Edited by PMS Hacker and Josephy Raz. Oxford: Claredon Press, pp. 58-84.

Dworkin, Ronald. 1997. Taking Rights Seriously. London: Bloomsbury.

Dworkin, Ronald. 1998. Law's Empire. Oxford: Hart Publishing.

Finnis, John. 1981. Natural Law and Legal Reasoning. In Natural Law. Edited by Robert George. Oxford: Claredon Press, pp. 134-57.

Finnis, John. 1984. The Authority of Law in the Predicament of Contemporary Social Theory. Notre Dame Journal of Law, Ethics and Public Policy 1: 115-37.

Finnis, John. 1996. The Truth in Legal Positivism. In The Autonomy of Law. Edited by Robert George. Oxford: Claredon Press, pp. 195-214.

Fuller, Lon L. 1958. Positivism and Fidelity to Law-A Reply to Professor Hart. Harvard Law Review 71: 630-72. [CrossRef]

Fuller, Lon L. 1969. The Morality of Law. Yale: Yale University Press.

Gauthier, David. 1987. Taming Leviathan. Philosophy \& Public Affairs 16: 280-98.

Gewirth, Alan. 1978. Reason and Morality. Chicago: Chicago University Press.

Gewirth, Alan. 1996. The Community of Rights. Chicago: Chicago University Press.

Hart, HLA. 1961. The Concept of Law. Oxford: Oxford University Press.

Hart, HLA. 2012. The Concept of Law, 3rd ed. Oxford: Oxford University Press.

Hobbes, Thomas. 2005. Leviathan. Chestnut Hill: Elibron Classics.

Jansen, Nils. 1998. The Validity of Public Morality. Archiv fur Recht und Sozilphilosophie 84: 12-13.

Kant, Immanuel. 1956. The Critique of Practical Reason. Indianapolis: Bobbs-Merrill.

Kant, Immanuel. 1996. The Metaphysics of Morals. Cambridge: Cambridge University Press.

Kant, Immanuel. 1997. Groundwork of the Metaphysics of Morals. Cambridge: Cambridge University Press.

MacCormick, Neil. 1992. Natural Law and the Separation of Law and Morals. In Natural Law Theory: Contemporary Essays. Edited by Robert George. Oxford: Claredon Press, pp. 105-33.

MacCormick, Neil. 1996. The Concept of Law and the Concept of Law. In The Autonomy of Law. Edited by Robert George. Oxford: Claredon Press, pp. 163-93.

Palmer Olsen, Henrik, and Stuart Toddington. 1999a. Law in its Own Right. Oxford: Hart Publishing.

Palmer Olsen, Henrik, and Stuart Toddington. 1999b. Legal Idealism and the Autonomy of Law. Ratio Juris 12: 286-310. [CrossRef]

Pattinson, Shaun. 2002. Influencing Traits Before Birth. Farnham: Ashgate Publishing.

Postema, Gerald. 1996. Law's Autonomy and Public Practical Reason. In The Autonomy of Law. Edited by Robert George. Oxford: Claredon Press, pp. 79-119.

Radbruch, Gustav. 1950. The Legal Philosophies of Lask, Radbruch and Dabin. Cambridge: Harvard University Press. Rawls, John. 1971. A Theory of Justice. Cambridge: Harvard University Press.

Raz, Joseph. 1975. Reasons for Action, Decision and Norms. Mind 84: 481-99. [CrossRef]

Raz, Joseph. 1999. Practical Reason and Norms. Oxford: Oxford University Press.

Raz, Joseph. 2006. The Problem of Authority: Revisiting the Service Conception. Minnesota Law Review 90: 1003.

Raz, Joseph. 2009. The Authority of Law. Oxford: Oxford University Press.

Toddington, Stuart. 2006. The Moral Truth About Discourse Theory. Ratio Juris 19: 217-29. [CrossRef]

Toddington, Stuart. 2013. Ronald Dworkin: To Be Continued. Student Law Review 69: 38-40.

Van der Burg, Wibren. 1999. Two Models of Law and Morality. Associations 3: 61-82.

Waldron, Jeremy. 1992. The Irrelevance of Moral Objectivity. In Natural Law Theory: Contemporary Essays. Edited by Robert George. Oxford: Claredon Press.

(C) 2019 by the author. Licensee MDPI, Basel, Switzerland. This article is an open access article distributed under the terms and conditions of the Creative Commons Attribution (CC BY) license (http:/ / creativecommons.org/licenses/by/4.0/). 